\title{
JUURNAL.RU
}

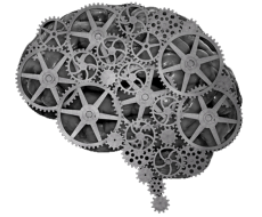

COMPANY GROUP "INTELLEKT"

\author{
Микушкин О.В., Мигунова Ю.С. \\ ФГБОУ ВО Ивановская пожарно-спасательная академия ГПС МЧС России \\ Иваново, Россия
}

doi: 10.18411/lj2016-5-2-17

\section{Особенности регуляции и саморегуляции психических состояний профессиональных контингентов ГПС МЧС России до, в условиях и после экстремальных ситуаций}

Спецификой служебной деятельности профессиональных контингентов ГПС МЧС России является работа в экстремальных условиях, которые, несомненно, оказывают разрушающее воздействие на психологическое здоровье специалистов.

В данной работе мы сделали попытку структурировать информацию об особенностях регуляции и саморегуляции психических состояний профессиональных контингентов до, в условиях и после экстремальных ситуаций.

Профессия специалистов сил постоянной готовности сопряжена с действием различных стрессогенных факторов. Неопределенность складывающейся обстановки, постоянное ожидание опасности, необходимость непрерывного анализа быстроменяющихся ситуаций, необходимость быстро принимать решения, от которых могут зависеть жизни людей, напряженная работа внимания, работа с человеческим горем - оказывают мощное и неоднозначное влияние на психику специалиста, требует мобилизации всех его физических и психических возможностей для эффективного решения стоящих задач. Чрезвычайно ответственные и опасные условия могут привести к различным психическим реакциям: от состояния тревожности до развития 
неврозов и психоза и привести к дезорганизации профессиональной деятельности. Таким образом, негативные психические состояния, возникающие у специалистов экстремального профиля при выполнение задачи повышенной трудности, влияют не только на исполнения им непосредственных профессиональных обязанностей, но и оказывают разрушающее действие на здоровье специалиста.

Проявление этих реакций могут последовать за событием сразу или отсрочено, через определенный промежуток времени. Здесь важна помощь психологов, медиков, сослуживцев, но многое зависит и от самого специалиста экстремального профиля.

Регуляция и саморегуляция психических состояний до начала деятельности в экстремальной ситуации, обеспечивающая психологическую защищенность профессиональных контингентов. Она достигается высококвалифицированной психологической подготовкой, которая является составной частью профессиональной подготовки.

Психологическая подготовка личного состава позволяет противостоять психотравмирующему воздействию экстремальных условий деятельности, решая следующие основные задачи:

1) формирование высокой эмоционально-волевой психологической устойчивости, то есть способности не поддаваться отрицательным разрушающим психическим состояниям (страх, тревога, беспокойство, неуверенность в себе и своих сослуживцах и т.д.), сохранять самообладание в опасных для жизни ситуациях;

2) формирование психологической готовности к выполнению поставленных задач и осуществлению активных, решительных, эффективных действий.

3) формирование устойчивой установки на выживание, которая ведет к развитию разумного и мотивированного риска, преодолению чувства страха. 
Навыки уверенного выхода из стрессовых ситуаций с минимальными потерями помогают привить психотерапевтические тренинги, моделирующие представления о возможных стрессовых ситуациях и реакции на эти ситуации.

Мероприятия, направленные на регуляцию и саморегуляцию психических состояний профессиональных контингентов, возникающих в условиях экстремальных ситуаций, могут иметь как краткосрочный характер, так и оказывать пролонгированное профилактическое действие.

В качестве стабилизирующих факторов психических состояний специалистов экстремального профиля могут выступать: благоприятный психологический климат в семье и в рабочем коллективе; наличие устойчивых дружеских связей; наличие возможности заниматься деятельностью, приносящей удовольствие (хобби, например); здоровый образ жизни; занятия спортом и т.п.

Специалист сил постоянной готовности должен уметь контролировать себя и свое поведение во время действия экстремальных факторов, своевременно определять симптомы психологических проблем у себя и у своих товарищей, а также быть готовым к помощи своим сослуживцам при возникновении у них неблагоприятных психических состояний (раздражительность, внезапные слезы, беспокойство, отчаяние и т.п.)

Целями регуляции неблагоприятных психических состояний в момент воздействия стрессогенных факторов, могут выступать: стабилизация состояния; снятие или уменьшение острых симптомов стресса; восстановление независимого функционирования.

Для оптимизации и управления своим функциональным состоянием в сложных условиях деятельности специалистами экстремального профиля применяются методы психической саморегуляции (ПСР).

К приемам психической саморегуляции относятся: управление дыханием и тонусом скелетных мышц, самовнушение, визуализация и т.д. 
С целью оказания эмоциональной поддержки сослуживцам в период воздействия стрессогенных факторов можно использовать такие простые приемы стабилизации состояния, как визуальный и тактильный контакты, ободряющие слова, уместные шутки.

Психическая саморегуляция в экстремальных условиях - средство повышения эффективности деятельности специалиста, минимизирующее негативные последствия стресса. Овладение навыками ПСР происходит во время психологической подготовки до наступления экстремальной ситуации.

Для профилактики стрессовых состояний также могут использоваться: рефлексотерапия, релаксационная музыка, библио-, аромато-, ланшафтотерапии, электрофизиологическая, физиолого-гигиеническая, физиологической регуляции (массаж, душ) [1].

Регуляция и саморегуляция психических состояний профессиональных контингентов может также проводится после воздействия экстремальных факторов.

Одним из самых сложных состояний у специалистов экстремального профиля является посттравматическое стрессовое расстройство, которое может проявиться как сразу после сильной стрессогенной ситуации, так и через некоторое время после воздействия негативных факторов (ПТСР).

Симптомами посттравматического стрессового расстройства являются: потеря сна и аппетита; навязчивые воспоминания; кошмарные сны о пережитом событии; ухудшение настроения при упоминании о событии; потеря способности переживать сильные чувства и эмоции; частичное ослабление памяти; стремление избегать мысли и чувства, связанные с пережитой психотравмирующей ситуацией; чувство "укороченного будущего"; потеря жизненных перспектив; сложности в концентрации внимания; раздражительность; пугливость.

Профилактика ПТСР является неотъемлемой частью системы профилактики негативных последствий профессионального стресса. Одним из 
методов работы с ПТСР является психологический дебрифинг, который представляет собой организованную и четко структурированную работу (беседу) психолога с группой специалистов сил постоянной готовности, совместно переживших одну и ту же травматическую ситуацию (например, принимали участие в ликвидации последствий одной ЧС).

Психологический дебрифинг направлен на минимизацию отрицательных психологических последствий и предупреждение развития симптомов ПТСР. Такой эффект достигается путем проработки впечатлений и эмоций всех участников и уменьшения тревоги и напряжения каждого, за счет проговаривания собственных чувств. Дебрифинг является видом групповой терапии, предусматривающей возможность обмена впечатлениями участников, что позволяет специалистам осознать и принять опыт, подготовиться к адекватному восприятию своего последующего состояния и возможности обращения за психологической помощью.

O возможной стабилизации психического состояния специалиста экстремального профиля может свидетельствовать восстановление функционального состояния личности, обретение чувства контроля ситуации и своего поведения, появление ресурсов для совладания с проблемой. На восстановление после тяжёлых травматических событий требуется длительное время и желание человека, пережившего травму, выйти из негативного состояния.

Многочисленные исследования в области психологии экстремальных ситуаций и изучение особенностей поведения человека и закономерностей его деятельности в экстремальных условиях позволяют качественно проводить подготовку специалистов сил постоянной готовности, сопровождать их деятельность, разрабатывать меры защиты от травмирующего воздействия психогенных факторов.

Особенности регуляции и саморегуляции психических состояний профессиональных контингентов до, в условиях и после экстремальных 
ситуаций обусловлены личностными особенностями специалистов данного профиля такими, как эмоциональная стабильность, толерантность к стрессу, средний уровень личностной и ситуативной тревожности, стеничность реакций на сложности и опасность, умеренная склонность к риску, уверенность в себе. Также имеют значение особенности конкретной профессиональной и служебной деятельности.

Своевременное осуществление регуляции и саморегуляции психических состояний, проявляющихся во время профессионально-служебной деятельности в экстремальных ситуациях, является профилактическим инструментом для поддержания психофизиологических ресурсов и работоспособности на адекватном уровне, а также сохранения здоровья профессиональных контингентов.

\section{Литература:}

1. Бодров В.А. Психологический стресс: развитие и преодоление. М.: ПЕР СЭ, 2006.

2. Психология экстремальных ситуаций: учебное пособие для студентов высш. Учеб. Заведений / [Т.Н. Гуренкова, И.Н.Елисеева, Т.Ю.Кузнецова, О.Л. и др.]: Под общ. Ред. Ю.С. Шойгу. М.: Смысл; Академия, 2009.

3. Психология экстремальных ситуаций для спасателей и пожарных [Текст] // Под общей ред. Ю.С. Шойгу. М.: Смысл, 2007. - 319 с.

4. Смирнов Б. А., Долгополова Е. В. Психология деятельности в экстремальных ситуациях. - М.: Гуманитарный центр, 2007. - 276 с. 